\title{
Broadening the Perspectives of South African English and Afrikaans Research (An Interview with David L. Gold
on his Work in these Fields)
}

\author{
Roy S. Rosenstein, American University of Paris, France
}

\begin{abstract}
David L. Gold is a student of South African English and Afrikaans who looks at these two languages in the context of several other Germanic languages, as well as other Indo-European and certain non-Indo-European languages. He suggests that the traditional comparison of Afrikaans only with European Dutch be supplemented by comparing it with New Netherland Dutch, which, like Afrikaans, began as a non-European variety of Dutch in the seventeenth century. A comparison of Afrikaans and New Netherland Dutch sheds light not only on those two languages but on earlier European Dutch too.

Gold suggests that the etymology of Afrikaans lexemes not be limited to their form but be extended to their meanings as well. If effect is given to that suggestion, we see that South African English has had greater influence on Afrikaans vocabulary than hitherto believed, i.e., the meanings of many Afrikaans lexemes are of English origin, although the lexemes themselves are not of that origin.

David L. Gold is also a student of Jewish aspects of South African English and Afrikaans. Most Jews who have settled in South Africa have been native speakers of Yiddish and it is only natural that traces of their native language can be found in their English or Afrikaans. A number of those vestiges are found in the speech of their descendents too (even if they do not know Yiddish) and a small number of them have been adopted by non-Jewish South Africans as well. Investigation of the influence of Yiddish on South African English and Afrikaans requires a good knowledge of the varieties of Yiddish brought to South Africa (in the early days: Western Yiddish; beginning in the late nineteenth century: Northeastern Yiddish), varieties of Jewish English spoken in other countries (for comparison with Jewish South African English), and Jewish Dutch (for comparison with Jewish Afrikaans).

Another Jewish aspect of South African English and Afrikaans which David L. Gold has looked into is non-Jewish usages of Jewish interest, like words meaning 'Jew' and idioms referring to Jews. All of this material of Jewish interest needs to be recorded and compared with similar material in other languages.
\end{abstract}

Keywords: AFRIKAANS, AMERICAN ENGLISH, ARABIC, ARMENIAN, BULGARIAN, CAPE-COLORED ENGLISH, CARIBBEAN DUTCH, COUNTING-OUT RIMES, DIGLOSSIA, DUTCH, ENGLISH, ETHNOLECTS, ETYMOLOGY, FAMILY NAMES, FRENCH, GERMAN, 
JEWISH AFRIKAANS, JEWISH AMERICAN ENGLISH, JEWISH BRITISH ENGLISH, JEWISH ENGLISH, JEWISH IRISH ENGLISH; JEWISH JAMAICAN ENGLISH, JEWISH SOUTH AFRICAN ENGLISH, LANGUAGE PLANNING, LANGUAGES IN CONTACT, LEXICOGRA. PHY, LEXICOLOGY, MARATHI, NEOSEMANTICISMS, NEW NETHERLAND DUTCH, PLACE NAMES, PORTUGUESE, SERBOCROATIAN, SOUTH AFRICAN ENGLISH, TURKISH, YD. DISH, ZEELAND DUTCH

\section{Opsomming: 'n Verruiming van die navorsingsperspektiewe op Suid-Afri-} kaanse Engels en Afrikaans ('n onderhoud met David L. Gold oor sy werk op hierdie gebiede). David L. Gold is 'n navorser van Suid-Afrikaanse Engels en Afrikaans wat hierdie twee tale teen die agtergrond van sowel verskeie ander Germaanse tale as ander IndoEuropese en sekere nie-Indo-Europese tale bestudeer. Hy doen aan die hand dat die tradisionele vergelyking van Afrikaans slegs met Europese Nederlands aangevul word met 'n vergelyking van Afrikaans met Nieu-Nederlandse Nederlands wat net soos Afrikaans as ' $n$ nie-Europese variëteit van Nederlands in die sewentiende eeu ontstaan het. ' $n$. Vergelyking van Afrikaans met NieuNederlandse Nederlands werp lig nie slegs op hierdie twee tale nie, maar ook op vroeëre Europese Nederlands.

Gold stel voor dat die etimologie van Afrikaanse lekseme nie tot hulle vorm beperk word nie maar ook tot hulle betekenisse uitgebrei word. Indien hierdie voorstel toegepas word; sal dit blyk dat Suid-Afrikaanse Ėngels 'n groter invloed op die Afrikaanse woordeskat gehad het as wat tot dusver geglo is, d.w.s. die betekenisse van baie Afrikaanse lekseme is van Engelse oorsprong, alhoewel die lekseme self nie van Engelse oorsprong is nie.

David L. Gold is ook ' $n$ student van die Joodse aspekte van Suid-Afrikaanse Engels en Afrikaans. Die meeste Jode wat hulle in Suid-Afrika gevestig het, was moedertaalsprekers van Jiddisj, en dit is bloot natuurlik dat spore van hulle moedertaal nog in hulle Engels en Afrikaans voorkom. 'n Aantal van hierdie oorblyfsels kan ook gevind word in die taal van hulle afstammelinge (selfs al ken hulle nie self Jiddish nie), en enkele gevalle word ook gebruik deur nie-Joodse Suid-Afrikaners. 'n Ondersoek na die invloed van Jiddisj op Suid-Afrikaanse Engels en Afrikaans verg ' $n$ deeglike kennis van die vorme van Jiddisj wat na Suid-Afrika gebring is (in die vroeë jare: Westerse Jiddisj; sedert die laat neëntiende eeu: Noordoostelike Jiddisj), variasies van Joodse Engels gepraat in ander lande (ter vergelyking met Joodse Suid-Afrikaanse Engels) en Joodse Nederlands (ter vergelyking met Joodse Afrikaans).

Nog 'n Joodse aspek van Suid-Afikaanse Engels en Afrikaans waaraan David L. Gold aandag geskenk het, is die nie-Joodse gebruike van woorde wat van Joodse belang is, soos woorde wat "Jood" beteken en idiome wat na Jode verwys. Al hierdie materiaal wat van Joodse belang is, behoort opgeteken en met soortgelyke materiaal in ander tale vergelyk te word.

Sleutelwoorde: AFRIKAANS, AMERIKAANSE ENGEELS, ARABIES, ARMEENS, BULGAARS, DIGLOSSIE, DUITS, ENGELS, ETIMOLOGIE, ETNOLEKTE, FRANS, JIDDISI, JOODSAMERIKAANSE ENGELS, JOODS-BRITSE ENGELS, JOODSE AFRIKAANS, JOODSE ENGELS, JOODS-IERSE ENGELS, JOODS-JAMAIKAANSE ENGELS, JOODS-SUID-AFRIKAANSE ENGELS, KAAPSE KLEUIRLING-ENGELS, KARIBIESE NEDERLANDS, LEKSIKOGRAFIE, LEKSIKOLOGIE, MARATHI, NEDERLANDS, NEOSEMANTISISMES, NIEU-NEDERLANDSE NEDERLANDS, PLEKNAME, PORTUGEES, SEEUSE NEDERLANDS, SERWO-KROATIES, 
SUID-AFRIKAANSE ENGELS, TAALBEPLANNING, TALE IN KONTAK MET MEKAAR, TURKS, UITTELRYMPIES, VANNE

Q.

How did you become interested in Afrikaans and South African English?

I grew up speaking Yiddish and English. With those two languages, it was fairly easy to teach myself to read German. Then, with those three languages, Dutch. And finally, with those four languages, it's easy to learn to read Afrikaans. As a linguist with an interest in Jewish languages, English, etymology, lexicography, family names, and some other topics, I've been able to put my reading knowledge of Afrikaans to good use.

Strange as it may seem, South African English and Afrikaans are useful in studying Dutch influence on New York City English, a subject which attracts me for a personal reason. Being a native of New York City (which until 1664 was called New Amsterdam and was part of New Netherland, a Dutch colony), 1 became interested in New York City English, specifically in how its vocabulary differs from the English spoken in other parts of the United States. One of the reasons New York City English is different is that it's been influenced by Dutch more than most other varieties of American English have. Today, that influence is hardly to be discerned, but as you go back in time, you find that the number of Dutch-origin usages increases.

Many of these Dutch-origin usages in New York City English and, more broadly, in American English had been identified before I became interested in the subject, but a number of them had not been. In American Speech and Leuvense Bijdragen, l published three articles on the word sliding pon/sliding pond, which was once commonly used in New York City to designate a children's slide (as in a playground). Growing up, 1 knew only sliding pond. It wasn't until my early thirties that I learned that outside Greater New York City the word (in either of its forms) was not used. It's based on Dutch glijbaan or some synonymous word ending in -baan. Until my articles on this word were published, it had been recorded only seldom and its etymology was unknown.

Since the three articles on sliding pon/sliding pond were published, l've gathered new material on the word and now plan to publish a more comprehensive treatment. After that, I'll go on to report on more vestiges of Dutch in New York City English in particular and American English in general.

\section{Q. But how do South African English and Afrikaans enter the picture?}

If you suspect that a certain usage in New York City or American English is from Dutch, your hunch is strengthened (but not proven) if three conditions are met: [1] you can find the same usage in South African English, [2] you're 
certain that in South African English the usage is of Afrikaans origin, and [3] you can't find the usage in any other variety of English. In such cases, you conclude that the New York City or American usage is probably of Dutch origin. That is, both of the English usages - in the United States and in South Africa - presumably go back to the same non-immediate source: European Dutch. South African English can thus serve as the basis for drawing up a checklist of usages in New York City or American English that may be of Dutch origin.

An important word here is checklist. The possibility of chance resemblance (convergence) always exists. That is, the researcher must constantly be on the lookout for the following situation: a certain usage in South African English may indeed be from Afrikaans (and in Afrikaans it is from Dutch), but that same usage in New York City or American English happens not to be from Dutch. Hence the checklist is merely an inventory of usages to be examined. Some may in fact tum out to be of Dutch origin and some may turn out not to be.

Students of American English can thus benefit from an examination of South African English. It also follows that students of South African English can profit from a look at New York City and American English, which may serve as the bases for drawing up checklists of usages in South African English that could be of Afrikaans origin.

Q. Can you give me an example of how students of South African English and American English can be of service to one another?

In South African English, the word forget means, inter alia, 'to leave [somethingl behind unintentionally'. For example, "I forgot my book on the table." That use of the word has been attributed to Afrikaans (cf. vergeet in the same sense). In the English of New York City (if not of the entire United States), we find exactly the same usage. Here, for instance, is a quotation from The New York Times of 6 May 1992: "As Mrs. Lipstein spoke, she noticed that a stranger had forgotten her sunglasses on the counter" (p. B3). Since the South African English usage is said to be of Afrikaans origin, we naturally ask whether the New York City English one is of New Netherland Dutch origin. If it is, we should be able to take both the New York City and South African English usages back to a common source, European Dutch.

However, if it tums out that forget in this sense in New York City English is not of New Netherland Dutch origin (let's assume, for argument's sake, that research showed the usage to go back to older British English), we might question attribution of the South African English usage to Afrikaans. If the American English usage could, for example, be of older British origin, so too could the South African English one (or, at least, of both Afrikaans and British English origin). 
Although I once entertained the possibility that forget in this sense might be of Afrikaans origin in South African English (others have indeed said it is) and of New Netherland Dutch origin in American English (in which case, the usage could probably be taken back further, to European Dutch), it's clear that this is a universal and standard English usage: at forget, the second edition of the Oxford English Dictionary has 'to omit to take, leave behind inadvertently' (with no condemnation or any kind of restrictive label), giving non-SouthAfrican citations from before 1300,1535, 1596, 1766, and 1860 . Therefore, at most, Afrikaans reinforces this usage in South African English. One should not condemn it as substandard, as at least two South African observers of South African English have.

We must now ask whether Afrikaans vergeet in this sense is due to English influence (or, at least, reinforced by English forget). Since one of the meanings of Dutch vergeten is 'uit onoplettenheid [iets] ergens achterlaten' (= sense III.7 in the Woordenboek der Nederlandsche Taal), as in "Ik moet terug naar de bibliotheek, want ik vergat mijn boek bij de balie" or "Ik moet terug naar het hotel, want ik vergat mijn paraplu bij de receptie," it's virtually certain that the Afrikaans usage is of Dutch origin. All three languages thus converge, so that the most that has happened is that Afrikaans and South African English reinforce each other in this respect. It would thus not be correct to speak of outright Afrikaans influence on South African English or vice versa as far as the use of these verbs is concerned.

New York City English (or, more broadly, American English) and South African English are thus suited for comparison with each other because both have been in contact with varieties of the same language (Dutch) or with languages that are closely related to each other (Dutch and Afrikaans): New Netherland Dutch in the case of American English, and South African Dutch and Afrikaans in the case of South African English. The periods of contact and the extent of the contact, however, are different. New Netherland existed for only a short time: in 1609, Henry Hudson, in the service of the Dutch West India Company, explored the river later named for him; by 1613, the Dutch had built four houses on Manhattan Island; in 1621, New Netherland was founded, but the first permanent colonists did not arrive until the spring of 1623; in 1664, Great Britain seized the colony; for part of 1673 and 1674, it was again in Dutch hands, but in 1674 the Netherlands officially ceded New Netherland to Great Britain (Leisler's Rebellion, in 1691, aimed at restoring Dutch control, failed). Even after Dutch rule over New Netherland ended, the Dutch language continued to lead a vigorous existence in New York and New Jersey (as the British had renamed New Netherland) until the American Revolution. Then it began to decline, although even as late as the 1830 s Dutch could still be heard on the streets of New York City. In the Hudson Valley and parts of New Jersey, the language survived into the early years of the twentieth century and even today at least two men are alive who learned New Netherland Dutch from their parents as their first language (Charles Gehring tells me that one of 
them is L.G. van Loon and that the other one wishes to remain anonymous). New Netherland Dutch thus began going out of use in the late eighteenth century, whereas Afrikaans has led a vigorous existence ever since Dutch was brought to southern Africa.

Q. If I may inject a word, Charles T. Gehring, who wrote his doctoral dissertation at the University of Indiana on New Netherland Dutch, is director of the New Netherland Project, whose principle aim is to translate into English and publish the approximately 12,000 pages of records of the Dutch West India Company which relate to New Netherland, and the organizer of the Rensselaerswyck Seminar, an annual conference of people engaged in research on New Netherland.

Yes, quite so. To go on: also, as a result of outmarriage and cultural assimilation, the New Netherland Dutch have disappeared as an ethnic group in the United States. Many Americans know that they're of partial New Netherland ancestry and many of those people who are well-to-do belong to the Holland Society, a fraternal organization with headquarters in New York City. Periodically, "Dutch festivals" are held in Albany (which is built on the site of Fort Orange, a Dutch outpost). Charles Gehring tells me that some elderly people remember some isolated words and phrases in New Netherland Dutch from their childhood and that many recall the nursery rime Trip a Trop a Trontie. The Dutch language, culture, and society of New Netherland are thus for all practical purposes like the Cheshire cat: the cat has disappeared, leaving only its smile. In contrast, Afrikaans, Afrikaans culture, and Afrikaner society are alive.

Those differences between New Netherland Dutch and Afrikaans are reflected in American and South African English: New Netherland Dutch has been a minor influence on New York City (or American) English, whereas Afrikaans has been the major non-English influence on South African English. Dutch and English are no longer in contact in the United States or South Africa, whereas Afrikaans and South African English continue to be in contact and influence each other. Much more material is available for the study of Afrikaans than for New Netherland Dutch, but as a student of several obsolescent and supposedly obsolete lects, I'm often surprized at what does tum up if one looks hard enough: it's probable that not all Dutch texts written in New Netherland (and, later, New York and New Jersey) have been uncovered, whether they are now in public or private hands, and it's possible that elderly people can be pumped for still more vestiges of the spoken language. Those looking for spoken vestiges in the twentieth century have interviewed mostly Whites, but Blacks too used New Netherland Dutch, likewise down to the twentieth century, although little has been recorded of their speech. I suspect that Black New Netherland Dutch may still be partly recoverable from elderly people. 
When a language ceases to influence another language, as is the case of Dutch and American English, what happens to the borrowings is unpredictable. Certain ones may continue to be used. Others may come to be used less. Still others may go out of use altogether. Here are some examples from American English. The word coleslaw, of New Netherland Dutch origin, is now universal in American English and all indications are that it is here to stay. The closure of American English to Dutch influence has thus had no effect on the secure position of coleslaw in American English. The word sliding pon/sliding pond, on the other hand, is obsolescing. A smaller percentage of New Yorkers know the word today than when I was a child. The closure of American English to Dutch influence thus had an adverse effect on the word: without the support of Dutch, it began going out of use. American English kill 'stream, channel', likewise from New Netherland Dutch (kil), hasn't fared well either: it now survives only in place names (Arthur Kill, Catskill, Fishkill, Fresh Kills, Great Kills, Kill Van Kull, Outer Kill, Peekskill, Schuylkill River, Val-Kill, Varkenskill, Whorekill, and a few others; cf. Dutch Kills, the now forgotten name of a town incorporated into Long Island City, New York, in 1870), but the average English-speaker has no idea what kill means in these names and doesn't use the word as a common noun. And some Dutch-origin usages have probably disappeared completely, like blummie 'flower'.

\section{Q. Isn't Whorekill an unusual place name?}

I don't know how it came about. The southernmost Dutch settlement in what is now the United States was on a cape which the Dutch called Henlopen. This settlement, in what is now Delaware, was first called Zwannendael, later Whorekill, and is now called Lewes. Perhaps Whorekill was a facetious name given by English-speakers or perhaps this name does not contain English whore at all.

To get back to the discussion: thus, as Dutch receded into the background in New York and New Jersey, the number of Dutch-origin usages in American English fell (but some have remained as part of the core vocabulary and others are marginal). It's not only the disappearance of the New Netherland Dutch language which led to a decrease in the number of such English usages, but also the disappearance of the New Netherland Dutch people into the American woodwork. The people simply assimilated, eventually losing almost all of their Dutchness, retaining at most a family name and/or, more rarely, a given name (like Comelius). One normally expects religious institutions to be conservative, but even the Dutch Reformed Church in America eliminated the word Dutch from its name (in 1867) as jts members became more and more American and less and less Dutch. Today, most of its members are not of New Netherland Dutch origin, though the church still uses few Dutch-origin religious. 
In South Africa, Dutch has disappeared as far as the English-speaking population is concerned. Hence South African English is now closed to Dutch influence. The number of Dutch-origin usages in South African English may remain the same or decrease, but it won't rise. Afrikaans, on the other hand continues to influence South African English. Hence the number of Afrikaansorigin usages will in all likelihood go up. If any usages of Afrikaans-origin in South African English obsolesce, that will probably be only because people no longer need them, not because Afrikaans is absent as a reinforcement. Because of the disappearance of New Netherland Dutch in contrast to the continuing presence of Afrikaans, today's average speaker of American English does not know that lexemes like coleslaw, cookie, cruller, play hooky, poppycock, Santa Claus, sliding pon/sliding pond, spook, stoop (in front of a building), waffle (food), and waffle iron, to name just a few of the borrowings from New Netherland Dutch, are of non-English origin, whereas today's average speaker of South African English is quite aware of the Afrikaans origin of words like kas, katel, and katkop.

Even the spelling of these lexemes plays a role: in the case of American English, the spelling blinds us to their Dutch origin, whereas and in the case of South African English, it reminds us of their Dutch or Afrikaans origin. Thus, American English lexemes of New Netherland Dutch origin tend to be respelled following rules of English spelling, whereas South African English items of Afrikaans (or Dutch) origin tend to be spelled as in Afrikaans (or Dutch), that difference being due to the disappearance of written Dutch in the United States vs. the continuing presence of written Dutch and written Afrikaans in South Africa, hence their continuing influence as a reinforcement of the traditional spellings. A good example of the difference is American English stoop vs. South African English stoep. There's nothing un-English about the spelling of stoop, but stoep has oe, which is unusual for English, hence a reminder that the word is of non-English origin. Likewise with respect to wordinitial $k$, which is generally a sign in English that the word is a borrowing from some other language, usually German, Dutch, Afrikaans, or Yiddish.

Whereas the spelling of American English non-proper lexemes of New Netherland Dutch origin has been fully anglicized in most if not all cases, American place names of that same origin may be classified along a continuum: between the two extremes of full retention of Dutch spelling and of full anglicization, we find various intermediate stages. For example, Spuyten Duyvil ( $=$ full retention of Dutch spelling), Harlem (= fully anglicized respelling of Haarlem, but with the net result being only a slight change), the Bowery (= fully anglicized respelling of die Bouwerij 'the Farm', with moderate changes), Hempstead ( = fully anglicized respelling of Heemstede [with $p$ due to the influence of Hampstead, near London, England, and now part of it]), Brooklyn (= fully anglicized respelling of Breuckelen 'Broken Land', with the result that a name which was meaningful to Dutch-speakers is meaningless to English-speakers), Tenafly (= fully anglicized respelling of Tiene Vly 'Ten Swamps', with the same 
result as in the previous example), Staten Island (= retention [with a slight simplification of spelling identical to the one seen in Haarlem $\rightarrow$ Harlem] of the first part of Staaten Eylandt [which name the Dutch gave to the island in honor of the States-General of the Dutch Republic] and translation of the second part), Midwood (= translation of at least the second morpheme of Midwout; since both Dutch and English have mid, the first morpheme of Midwood shows both retention and translation), Coney Island (= full translation of Konynen Eyland, in contrast to Staaten Eylandt $\rightarrow$ Staten Island, in which the first part has not been translated, with the result that Staaten, which was meaningful to Duitch-speakers, has become Staten, which is meaningless to English-speakers), North River (= full translation of Nordrivier), Broadway (= full translation of Breed Wegh), and hook 'curving cape; curving headland', as in Corlear's Hook, Jeffrey's Hook, Red Hook, and Sandy Hook (= translation of Dutch hoek, as in Hoek van Holland). Full replacement of the Dutch name (like Rustdorp changed to Jamaica [now in Queens, NY]) illustrate even more radical anglicization.

Some of the changes are unusual in other ways. According to some, die Helle-Gat means 'the Beautiful Passage' and was the name which the Dutch gave to the East River (in what is now New York City). English-speakers, they say, folk-etymologized this name as Hell Gate, i.e., as if it meant 'the Gate to Hell', and, because of this ominous reference, applied Hell Gate only to the dangerous whirlpools caused by reefs in the narrow channel of the East River between the southwest side of Ward's Island and the northwest side of what is now Queens (the whirlpools were eliminated in 1876 when the Army Corps of Engineers blasted the reefs, thus making the channel easily navigable). According to others, die Helle-Gat originally meant 'the Hell Strait' and was always applied (whether in this Dutch form or its anglicized form, Hell Gate) to that dangerous channel. According to still others, die Helle-Gat originally meant 'the Narrow Passage' and was always applied to that channel. In any case, Hell Gate (which is now taken to mean 'the Gate to Hell') is an anglicization based on the written, not spoken, form of Dutch Gat, for if had been based on the spoken form, the end result would not have been be Gate. The name now survives mostly in Hell Gate Bridge, the name of a bridge spanning Ward's Island, Randall's Island, and Queens. Another noteworthy change concerns Schuylkil or Schuilkil, the name (literally 'Hidden Channel') which the Dutch gave to a river now in Pennsylvania. English-speakers adopted it as Schuylkill (doubling the $l$, as in all place names containing Dutch kil), but, not understanding the name, they added the generic word river, so that the full English name of the waterway is Schuylkill River, which is tautologous if you interpret it literally.

Several English place names reflect or may reflect folk-etymologized Dutch names. The Arthur Kill (the name of a waterway straddling the border between New York and New Jersey) honors no person bearing the given or family name Arthur. Rather, Arthur is a folk-etymology of Dutch achter (the Dutch called this waterway die Achter Kil 'the Back Channel'). The first element in the name Gramercy Park is an English-speaker's reinterpretation of Dutch 
Krom Moerasje 'Crooked Little Swamp', which is what the Dutch called a swamp where the park is now located. According to some, Turtle Bay was so named because of the turtles in the area. According to others, it was so named because this small bay was shaped like a turtle's back. And according to still others, Turtle is an English-speaker's reinterpretation of Dutch deutal 'unevenly curved sword', the bay having been so named by the Dutch because of its shape (supporters of the third explanation call attention to a nearby farm called Deutal Bay Farm). I rather think that the last explanation is the correct one, as shown by the name of the farm.

The borough of New York City officially called Bronx and informally known as the Bronx is said to have been named in honor of Jonas Bronck, an early settler there, but the story is a bit more complicated. Jonas Bronck was a Dane who settled in that part of New Netherland (it is sometimes though that the population of New Netherland was exclusively Dutch, but it was actually heterogeneous). People who visiting or intending to visit Bronck and his family would say "I'm going to the Broncks" and in time "the Broncks" was reinterpreted as the name of the area where he and his family lived. The Bronx is thus an English respelling of the Broncks, hence the areas was not named in his honor, but results merely from a folk etymology.

A problematic English place name is Flushing, which now designates part of Queens, NY. Some have written that it is English for 'flowing water' (in allusion to a meandering river there now called the Flushing River). Some have written that a group of people fleeing religious persecution in England settled in the seaport of the southwestern Netherlands known as Vlissingen in Dutch and Flushing in English; later they set sail for Massachusetts and, in 1654, left that English colony (again because of religious persecution), making their way to New Netherland, where they founded a village, which they named Flushing in honor of the Netherlands seaport which had given them refuge. And some have written that the Dutch founded the village in 1628, named it Vlissingen in honor of the Netherlands seaport, and the English-speakers in New Netherland consequently called it Flushing. I do not know which of the three explanations in correct.

The contrast between the tendency of non-proper lexemes to have anglicized spelling (let us generically call it "modern spelling") and of place names to retain (to various degrees) their spelling (generically "archaic spelling") is not limited to American English items of New Netherland Dutch origin. It was only some time after the French pronunciation of Liége changed from /ljež/to $/$ ljez / that the spelling was modified accordingly (to Liège). In Mexican Spanish, the now archaic spelling México is still used (and exclusively so), whereas in other varieties of the language Méjico is the norm. Certain Spanish given names and family names are now spelled in two ways: archaically (Xavier, Ximénez, Yglesias) and as modern spelling requires (Javier, Jiménez, Iglesias), yet the common noun from which the third name is derived (iglesias 'churches') is now spelled only in its modern form. Similarly in English, the common noun 
is now solely smith, whereas the family name is now Smith, Smithe, or Smythe. Similarly in South Africa: even after Afrikaans became official in 1925, Dutch place names in that country were not, as far as I know, replaced by Afrikaans ones. And even after Dutch spelling was modified in 1947, Dutch place names in South Africa were not changed to accord with the new rules. A South African place name which serves as an example of both kinds of conservatism is Stellenbosch. It should be *Stellenbos according to the spelling rules both of Afrikaans and of post-1947 Dutch, yet a non-Afrikaans, pre-1948 Dutch spelling has been retained to this day.

To get back to the three conditions, condition [3] can't always be met completely, but no matter. Take, for example, English cookie. The word is found only in American English, South African English, and Scots English (with not exactly the same meaning in all three varieties). Were condition [3] to be applied strictly, we'd have to discard this word from our checklist because it's found in a variety of English outside the United States and South Africa, but we include it anyway because it's clear that it shows the identical influence of New Netherland Dutch on American English and of South African Dutch and Afrikaans on South African English (the Scots English word is a borrowing from European Dutch).

Another reason for my interest in South African English is that linguists looking at a language from the outside - as observers rather than as participants - can often discem things which natives, that is participants, can't (that's in fact how I came to know that sliding pon/sliding pond is restricted to Greater New York City: someone from California once remarked on "this strange word" I'd used). As a non-speaker of South African English, I can often pick out usages which are typical of that variety of English more easily than speakers themselves. You can't tell what's different until you've made comparisons - and outsiders often make those comparisons more quickly and more accurately because they're looking at the fishbowl with a certain perspective rather than swimming around inside it. Since most students of South African English have been South Africans, I'm at a special advantage.

I might add that to my knowledge no one has ever compared Afrikaans and New Netherland Dutch, although it's a subject crying out for attention, especially since the two share two major features: they both derive from varieties of Dutch which were brought from the Netherlands within twenty-five years of each other, hence they are about the same age (New Netherland was founded in 1624 and Jan van Riebeeck landed in 1652), and both have a marked Southem Dutch character. The corpus of New Netherland Dutch is small enough that the topic could be treated in a dissertation or a monograph. Here are two of the many gems probably waiting to be unearthed: Branford 1991 lists sit up and opsit 'to court a girl by "sitting up" with her after the family have gone to bed' and derives them from Afrikaans opsit 'to court, woo', which it says is from Dutch opzitten 'to sit up'. That etymology implies that 'to court, woo' is an Afrikaans innovation, that is, such a meaning is, presumably, absent in Dutch 
opzitten. Yet / /pset / 'courting' was recorded in the English of one of the last speakers of New Netherland Dutch (Shetter 1958: 251). That is clearly not the English word upset with a new meaning, but an anglicization of the underlying New Netherland Dutch verb. Several questions with respect to this meaning thus need to be asked: [1] did New Netherland Dutch influence Afrikaans? [2] did Afrikaans influence New Netherland Dutch? [3] was the meaning present in seventeenth-century European Dutch, but simply failed to get recorded in that variety (though surviving in New Netherland Dutch and Afrikaans)? [4] do we have here merely a chance convergence, i.e., independent innovation in New Netherland Dutch and in Afrikaans? The answer to one of those questions must be yes. We may safely reply "no" to the first two questions, since New Netherland Dutch and Afrikaans were not in significant contact. The answer to the third question might be "yes" (what can students of seventeenthcentury European Dutch tell us?), but, if "no," then we must answer "yes" to the last question. My hunch is that the third possibility is the correct one. I would therefore first look for evidence in Southern Dutch (of Europe) for opzitten *to court, woo' and then in Northern Dutch (of Europe). If no evidence could be found, we would conclude either that [a] the New Netherland Dutch and Afrikaans usages are circumstantial evidence for such a usage in the seventeenth-century (Southern?) Dutch of Europe, although no direct evidence is available, or [b] that this is an instance of independent innovation.

Here is the second gem. European Dutch vallei, as far as I know, means only 'valley'. Yet South African English vlei and Afrikaans vlei mean 'a large shallow lake or swampy piece of ground'. The South African English word is clearly derived from the Afrikaans one, hence the question is whether the meaning 'a large shallow lake or swampy piece of ground' is an Afrikaans innovation or reflects an older European Dutch usage. However, as in the case of 'to court, woo', we find that New Netherland Dutch and Afrikaans usages are identical. Carpenter 1908: 62 listed American English vly/fly/vley/vlei/vlaie'a swamp, marsh, shallow pond'. The phonological and semantic identity between the Afrikaans and New Netherland Dutch words is striking. Again, Afrikaans influence on New Netherland Dutch is unlikely, as is New Netherland Dutch influence on Afrikaans. Independent innovation is possible (we should never forget that no language is static, hence Dutch in both New Netherland and southern Africa changed in certain, not necessarily identical, ways, as did European Dutch in ways in which extra-European Dutch may not have - all the more so if we use English to recover New Netherland Dutch or early Afrikaans: since English reflexes of New Netherland Dutch or Afrikaans items may be innovative, we must be certain not to attribute those innovations to the source language). 
The trick is to determine precisely where the innovation occurred. Q. Can you give me an example of one which is certain to have occurred in the reflex rather than in the etymon?

Greater New York City English has both sliding pon and sliding pond for 'slide'. Both forms go back to one or more New Netherland Dutch compound nouns ending in -baan (cf., for example, European Dutch glijbaan), but none of those European Dutch nouns is attested with /d/ (for New Netherland Dutch, no compound whatsoever has been recorded, though we may assume at least one on the basis of the English forms). Because sliding pon first designated a slippery area on a frozen pond that was suitable for sliding (before the word came to designate a slide in a playground for children), it's virtually certain that sliding pond is an English folk etymology of sliding pon that was induced by English pond. The innovation thus occurred in the English reflex rather than in the Dutch etymon.

To get back to the matter of analogs. However, the more analogs in Afrikaans and New Netherland Dutch which we record, the less probable it becomes that we have instances of independent innovation (how could there be so many chance similarities between the two?) and the more likely it becomes that Afrikaans and New Netherland Dutch are two tips of the SAME iceberg, whose submerged part is seventeenth-century spoken European Dutch basilect and mesolect, that is, Afrikaans and New Netherland Dutch may turn out to preserve features of European Dutch which are not known to us directly from European Dutch. You will not fail to notice, by the way, that in this example it is not only the meanings which are the same but the form as well: the Afrikaans and New Netherland Dutch words lack a vowel between the /v/ and the $/ 1 /$.

Shetter does refers to Afrikaans a few times (but not in connection with opzitten or vallei), so it is clear that I am not the first to see the value of comparing Afrikaans and New Netherland Dutch. The more points of comparison we have (European Dutch, New Netherland Dutch, Afrikaans, South African English, and American English), the better able we are to understand each of these languages. And the more analogs we find between New Netherland Dutch and Afrikaans, the less the likelihood that they are due to chance, hence the more valuable these two languages will be in reconstructing older spoken European Dutch. Thus, whereas researchers have often compared (a) Afrikaans and European Dutch OR (b) New Netherland Dutch and European Dutch, we actually need a THREE-WAY comparison or, even better, a SIX-WAY comparison (including British English, American English, and South African English). Again the word checklist is important, for the possibility of chance resemblance (convergence) between Afrikaans and New Netherland Dutch always exists (especially since both began with essentially the same raw material - seventeenth-century spoken Dutch of Europe), as does the 
possibility of chance resemblance between South African English and American English.

An example of the latter possibility is South African English the taal/the Taal/die taal 'Afrikaans' and now obsolete American English the Tawl 'Dutch'. The South African English usage is derived from Afrikaans die taal the language', which is derived from Dutch die taal 'the language'. The American English usage reflects the New Netherland Dutch pronunciation of Dutch die taal 'the language'. It's clear that semantic narrowing occurred somewhere along the line ('the language' $\rightarrow$ 'Afrikaans' and 'Dutch'). Here, in contrast to opzitten and vallei, I do not think that the semantic innovation occurred in European Dutch. Rather, it must have been in American English and in South African English - and it must have been independent in each language. That is, identical conditions led to identical results: English-speakers designated "the other language" (New Netherland Dutch and Afrikaans) simply by the words for 'the language' in that "other language." We therefore have nothing more than a coincidence in this instance.

Q. You say that "in South Africa, Dutch has disappeared as far as the English-speaking population is concemed." Hasn't it disappeared with respect to the Afrikaans-speaking population too? That is, aside from the study of Dutch in schools and the many Dutch place names, the language plays no role here.

l suspect that Dutch has continued to play a minor role in the development of Afrikaans, although an ever diminishing role, even after the de-officialization of Dutch in 1925. Take, for example, the Afrikaans words for 'zipper', rits and ritssluiter. The Dutch word is ritssluiting. Now it could be that the Afrikaans and Dutch words resemble one another only by chance, but I think that even after 1925 certain Afrikaans-speakers have looked to Dutch as the possible model for Afrikaans neologisms. I'm not implying that Dutch has been followed slavishly, only that certain Afrikaans-speakers may have gotten the idea for this or that coinage from Dutch. Remember that the zipper is a fairly new device. It was invented in the 1890 s but did not become popular until the 1930s. Indeed, J.B. Berns, head of the Dialectology Section at the P.J. Meertens Institute of the Royal Dutch Academy of Sciences, tells me that his earliest citation for ritssluiting is only from 1937. Although it could be sheer coincidence that the Afrikaans words resemble the Dutch one, I wouldn't be surprized if rits were a shortening of ritssluiter and the latter had been inspired by ritssluiting. If my analysis is correct, Dutch influence did not end in 1925.

Another example Afrikaans oordruk 'offprint', which is clearly based on Dutch overdruk 'offprint'. We may be certain that early Dutch-speaking settlers 
in southern Africa had no idea what an offprint was (if one may judge by English offprint, which is not attested to the 1880 s, we may say that the phenomenon, hence the concept, was not known until the mid-nineteenth century at the earliest). Therefore, unlike, say, "Dutch over $\rightarrow$ Afrikaans oor" (where the arrow indicates a phonological change that took place as the word was passed from generation to generation), in "Dutch overdruk $\rightarrow$ Afrikaans oordruk" we have a (twentieth-century?) literal translation (rather than a phonological change).

The vestiges of Dutch in South Africa and in the United States are thus similar in their lexical distribution: they tend to be place names and family names, that is, proper names, which is the segment of the vocabulary that is often most conservative. The remaining vestiges are non-proper lexemes in local languages. In the United States, that local language is mostly English, though New Netherland Dutch presumably influenced certain Native American languages too. In South Africa, that local language is English (could there be vestiges of Dutch in African languages of South Africa too?). Possibly the only major difference between the two countries concerns the post-1925 influence of Dutch on Afrikaans neology: as far as I can tell, that influence has no American analog. That is, after New Netherland came under British rule, European Dutch ceased to influence New Netherland Dutch. Shetter writes: "The Dutch of seventeenth-century New Netherland seems only in the last dozen years or so to have become finally a matter of the past. After the forty-odd years of Dutch sovereignty came to an end in 1664 the Dutch-speaking settlements flourished and spread, but they were for all practical purposes cut off from the mother country. The language, which from now on lived and developed independently of the Dutch of the Netherlands, survived a remarkably long time, but by the end of the nineteenth century it was in active use only around Albany, New York, and in the northernmost part of New Jersey. The latter settlements seem to have preserved best their identity as speech islands, and even the tide of Dutch immigration in the 1840s appears to have done little or no mingling with this isolated group no longer felt by the Dutch to be compatriots" (p. 243). Since the corpus of New Netherland Dutch is now almost closed (though, as I've said, we should still expect to uncover more written monuments and I wouldn't be surprized if more spoken vestiges were ferreted out from elderly people), the time has come for a comprehensive work on New Netherland Dutch, which would reprint and comment on all known primary and secondary sources, adding whatever newly recorded oral material could be gleaned. Such a work should contain material on New Netherland Dutch influence on other languages too (including place names) and once a book like that were available, students of Afrikaans would have as large a fund of information as possible for purposes of comparison with Afrikaans. An aspect of that comparison which should not be overlooked is place names, as l've suggested in Gold 1992: 98. 


\section{Q. Have you done any research in South Africa?}

I've never been to South Africa. That's been a benefit, for, as I say, it allows me to view the fishbowl from the outside. On the other hand, the number of as. pects of South African English which I can study is limited. Sociolinguistic topics, for example, are excluded because you have to be on the spot to see how language functions in society. Most subjects in phonology too are beyond my ken. But vocabulary is easily studied. With a mass of printed material in English and access to speakers of South African English outside South Africa, it's relatively easy to go through a text or listen to a speaker and pick out the usages which are absent in American English (hard to find, however, are lews who are native speakers of Afrikaans).

However, one mustn't think that something present in South African English and absent in American English is necessarily a usage which arose in South Africa or which is limited to South Africa. To determine which usages are South-Africanisms (by birth or by residence), one must also be acquainted with British English. Thus, a speaker of American English will be struck by the South African English verb post, as in "to post a letter," because we say mail in the United States. That, however, isn't a South African English innovation or a usage restricted to South Africa, for post is so used in British English too (which in this case is the source of the usage).

Although the number of topics I can investigate is indeed limited, the few which do lend themselves to research from afar are so broad that 1 have work galore. And, anyway, I have more research interests which keep me busy.

Q. And how does Afrikaans help in the study of Dutch influence on American English?

It goes without saying that you need to know Afrikaans if you want to use South African English in making a checklist of New York City or American English usages that are possibly from New Netherland Dutch. Assume this hypothetical situation: a certain usage is found in New York City (or American) English and in South African English. The researcher doesn't know Afrikaans or Dutch. The researcher thus doesn't know to what that usage common to both varieties of English should be ascribed: the influence of British English? The influence of New Netherland Dutch in the United States and South African Dutch and/or Afrikaans in South Africa? The influence of some other language or languages? South African English influence on the English of New York City or of the United States? New York City or American English influence on South African English? Convergence? Afrikaans is therefore essential to my study of Dutch influence on American English. Otherwise it would be an unknown factor, lurking in the background but never brought to the fore. 
Needless to say, you have to know Afrikaans to study South African English vocabulary too. For example, anyone approaching South African English from the outside will be struck by the use of slim in the sense of 'clever'. If you don't know Afrikaans, you might think that this is a specialized use of the English word slim (are thin people in South Africa, you might ask, for some reason considered clever?). However, if you know Afrikaans, you realize that this slim is not English slim 'slender' but a borrowing from Afrikaans, where the word is from Dutch slim (which happens to be the etymon of English slim 'slender', but that's another story). Being an outsider is therefore beneficial in identifying specifically South African English usages, but you have to observe more than English if you want to explain how they arose.

A major problem in the study of Afrikaans and South African English is deciding, with respect to any given usage, in which direction influence has gone, if any (as we've just seen with forget and vergeet). English influence on Afrikaans? Afrikaans influence on English? The influence of a third language (which is a kind of convergence) on both? Influence of English on Afrikaans (or vice versa), with subsequent mutual reinforcement of the usage (i.e., English reinforces the usage in Afrikaans and Afrikaans reinforces it in English)?

Having used the word checklist several times, I should say that any language can serve as the basis for compiling a checklist of investigable usages in another language. An example from Afrikaans, Yiddish, English, and Dutch will illustrate. Dutch distinguishes wij 'we' and ons 'us', but Afrikaans has neutralized that distinction, that is, Afrikaans ons means both 'we' and 'us' and Afrikaans has no reflex of wij. In Central Yiddish as spoken in Congress Poland and western Galicia, the same thing has happened: the distinction between mir 'we' and undz 'us' has been neutralized, with the latter word meaning both 'we' and 'us'. So too in English: the second edition of the Oxford English Dictionary has citations for us 'we' from 1607, 1699, 1737, before 1775, 1846, and 1880 (labeling it "now dialectal"), with citations from c. 1489, 1814, 1840, 1853 , and 1889 for $u s$ 'we' in apposition to a noun or an adjectival numeral (like "Us guys have to..." and "Us two have to..."). So too in the Dutch of Zeeland (l.B. Berns tells me that ons 'we' has been recorded at twenty-three points in that province). It's interesting that in all four cases the neutralization has favored the form which originally meant only 'us'. Is that an instance of convergence ( $=$ independent development in three Germanic languages) or, rather, can abandonment of the 'we' word be traced to a single source? It's probably safe to say that the Afrikaans usage is likely to be of Zeeland Dutch origin, but whether further links can be found is unclear. At least, however, the parallels have now been noted.

American English coleslaw, Santa Claus, and the Tawl suggest another.way in which Afrikaans and New Netherland Dutch are similar and another way in which they may be studied. Research on New Netherland Dutch and early Afrikaans has been hampered by the fact that their users had no desire to forge a language different from European Dutch. Their standard, at least in writing, 
was European Dutch. It is thus only by chance that we may glean the specificities of New Netherland Dutch and of early Afrikaans, that is, only when writers of Dutch in what are today New York, New Jersey, and South Africa happen to have deviated, whether consciously or unconsciously, from the European Dutch norm.

However, since both Afrikaans and New Netherland Dutch have influenced other languages (chiefly English, but also native languages of what are now the United States and South Africa), another way of recovering those specificities is by looking at those other languages. Although coleslaw, Santa Claus, and the Tawl clearly go back to European Dutch koolsla, Sinterklaas, and die taal, we may assume from the spellings $a w$ and $a u$ in these American English words that Dutch aa was pronounced /o:/ in New Netherland Dutch (which was once a feature of European Dutch south of Amsterdam). That feature is not, to my knowledge, found in written New Netherland Dutch, but we may assume its presence in the spoken language on the basis of allolingual evidence - which is to say that we also assume these English borrowings to have been made orally rather than from written Dutch texts (an entirely natural and justified assumption since New Netherland Dutch was preeminently a spoken language). Relevant here too is American English crawl 'pen for pigs or any kind of livestock; enclosure in shallow water on the seacoast for containing fish, turtles, etc.' (as in crab crawl, pig crawl, or unmodified crawl), a word which is used chiefly in the South Atlantic states and which is first recorded for the mid-seventeenth century. It is derived from Caribbean Dutch kraal 'idem', which is derived from Spanish corral '(animal) pen, fold; fish trap'. The aw of crawl is thus evidence that aa was rendered in Caribbean Dutch (at least to the mid-seventeenth century) as it was in New-Netherland Dutch. Caribbean Dutch kraal is a cognate (not a reflex) of Afrikaans kraal, which is a reflex of Portuguese curral (which is a cognate of Spanish corral).

Afrikaans-origin borrowings in South African English and other languages of Africa,might likewise shed light on earlier Afrikaans phonology. Since Dutch was official in South Africa until 1925, Afrikaans-speakers for a long time made an effort to write Dutch as best they could, even though that was not what they were speaking. It was a typical case of diglossia - people spoke $x$ language but wrote (or tried to write) $y$ language. Even though Afrikaans often shows through in written South African Dutch, Afrikaansisms interspersed in Dutch texts are not enough for an adequate investigation of Early Afrikaans. What the linguist would like to have is an abundance of early texts in pure Afrikaans. Since that is lacking, one must make due with what one has. The reconstruction of Early Afrikaans therefore proceeds along three lines: [1] present-day Afrikaans serves as the starting point for diachronic linguists who work back in time by the standard methods of internal reconstruction and comparative linguistics; [2] South African Dutch texts are gleaned for whatever non-European Dutch features they may contain; and, as illustrated 
with Tawl and coleslaw, [3] borrowings in other languages are examined to see whether they contain non-European Dutch innovations.

Those borrowings should be sought not only in speech but in written monuments too, like diaries and travel literature. Travelers often pick up bits and pieces of local languages from speech rather than from writing, especially as we go back in time, when much more was spoken than written. Naturally, the linguist must be on guard, for it is not always easy to interpret what travelers and other non-linguists were trying to record. Sometimes they do record written and not spoken forms (for example, Heinrich Lichtenstein's Travels in Southern Africa has "the Predikstoel," which is from predikstoel and not Afrikaans preekstoel [cited in Branford 1991: 251]). Sometimes their spellings are misleading or now uninterpretable. Sometimes the spelling conventions of the allolanguage do not permit them to record accurately what they have accurately heard (how, for example, would speakers of non-Scots English who do not have an $/ x /$ in their phonology record this Afrikaans phoneme?). And, even if written monuments are interpretable, they may reflect not Afrikaans or New Netherland Dutch pronunciation but the writers' reinterpretation of what they have heard. The distinction between, say, an Afrikaans word and an English word of Afrikaans origin is thus important, for once a word enters another language, it is usually subject to the phonology of that language. For various reasons, therefore, allolingual written monuments not infrequently contain altered forms, but even with those problems, earlier English and other allolingual texts as sources of New Netherland Dutch and of Early Afrikaans should not be neglected. The compilers of the Woordeboek van die Afrikaanse Taal do search nonAfrikaans sources and I hope that compilers of South African English dictionaries look at allolingual material too.

A comparison of Afrikaans and New Netherland Dutch could extend to more than just language. Say we have the Dutch or Afrikaans lyrics of a song but it's not known whether they were written. If at least similar lyrics were sung in New Netherland, chances are they were composed in Europe. Architecture, dances, dress, folk beliefs, folk remedies, games, recipes, stories, tunes, and other aspects of material and non-material culture can thus be compared too. The feasibility of comparative research depends on the availability of data, although, as I've said, much more is known about southern Africa than New Netherland.

And perhaps not only New Netherland could be brought into the picture: the Dutch had other colonies and trading posts in Africa at various times beginning in the late sixteenth century (Axim, Bereku, Cape Coast Castle, Crèvecoeur, Dixcove, Elmina, Gorce, Lüdzaamheid, Mouree, Nassau, Orange, Secondi, Sierra Leone, St. Sebastian, Vredenburg, and Whydah), South America (what are now Suriname, Guyana, and parts of Brazil), the Caribbean (Tobago and what are now the Netherlands Antilles), Asia (Bimpipatam, Cannanore, Calicut, Cochin, Colombo, Cranganore, Deshima, Firando, Fort Zelandia, Jafnapatam, Martaban, Negapatam, Negumbo, Pegu, Pointe de Galle, Pulicat, 
Quilon, Tenasserin, Trincomali, and various parts of what are now Malaysia and Indonesia), and Oceania (Cape Leeuwins, Dirk Hartog Island, Eendrachtsland, and Tasmanland), as well as on Amsterdam Island, Mauritius, and St. Helena. Although it would be naive to expect that Dutch material and nonmaterial culture left any substantial imprint in any but a few of those places, we can often never predict what stray datum might turn up that could shed light on Afrikaans or Afrikaans-medium culture. Deshima (also spelled Dejima) is especially interesting. The Dutch opened a trading post on this island in the harbor of Nagasaki in 1641 and operated it until 1854, when Japan was opened to Western trade. It was from Deshima that the Dutch introduced Western medicine and mapmaking into Japan and it was through this contact that Dutch came to influence Japanese, especially its medical terminology.

\section{Q. Tell me about your work on Jewish aspects of South African English and of Afrikaans?}

That subject consists of two parts. First, we know from sociolinguistics in general and from the study of Jewish languages in particular that wherever people are different - however they may be different - differences in language will be discernible. These differences can be major, as when group $x$ uses language $x$ and group $y$ uses language $y$, or they can be less than major, as when group $x$ uses language $x$ in certain ways and group $y$ uses language $x$ in different ways.

Most Jews settling in South Africa have been native speakers of Yiddish, although the language hasn't been long-lived in the country. Like many immigrants in all parts of the world, the older the Yiddish-speaking immigrants are at the time of their arrival, the better they know their Old-Country language and the less they learn a New-Country language. The younger the immigrants are, the more quickly they forget their Old-Country language and the faster and better they learn a New-Country language. The native-born children of immigrants have some knowledge of the Old-Country language (usually just rudiments of the spoken language), but they know less than their parents, their best language being a New-Country one. At most, the second native-born generation knows only bits and scraps of the Old-Country language, being, for all practical purposes, monolingual in a New-Country language (except those of the second native-born generation who are in close contact with an immigrant grandparent, in which case an elementary speaking knowledge of the OldWorld language is often passed on from grandparent to grandchild; however, after the grandparent dies, the grandchild often begins to forget the Old-World language - if there is no longer any occasion to use it - and may in fact forget it completely). The next generation knows next to nothing or absolutely nothing of the Old-Country language. 
If immigration is continuous, one may gain the impression that use of the old-Country language in the New Country has likewise been continuous, but that may be an illusion. Thus, one can say that Yiddish has been spoken in South Africa ever since the first Jews came to southern Africa, but that doesn't mean that the language has been transmitted from generation to generation, from parent to child, for any significant number of generations. Usually, in fact, it's transmitted for only one generation: from immigrant parents to their children. By the second native-born generation, Yiddish and Yiddish-medium culture are extinct. Actually, the only languages brought from Europe which have taken root in South Africa are English and Dutch (in Namibia, German too).

Since the end of the 1940s no significant numbers of Jews have been settling in South Africa. Hence the Yiddish-speaking immigrant generations are now either dead or elderly. Yiddish has been receding into the background, as the percentage of native-born Jews rises and as the native-born, with every new generation, become more South-Africanized - indeed, to a large extent, less and less Jewish. The number of Yiddishisms in the English or Afrikaans of South African Jews has, consequently, been decreasing, but some remain. Also, some specifically Jewish usages (not necessarily from Yiddish) are being added (from Israeli Hebrew), so that the English and Afrikaans of Jews in South Africa are still a bit different from those of non-Jews, but not by much.

Study of Jewish South African English and Jewish Afrikaans requires a knowledge of three additional languages: Yiddish (in two varieties: Western Yiddish and Northeastern Yiddish), Israeli Hebrew, and other varieties of Jewish English.

Q. Why are those two varieties of Yiddish, rather than any other, pertinent to South Africa?

The Jewish community of South Africa in former times consisted mostly of Western Ashkenazim, that is, Jews who trace their immediate ancestry to what in Jewish geography is called Western Ashkenaz (an area whose eastern boundary is more or less the 1939 boundary between Germany and Poland and its imaginary southward extension and whose westernmost reaches include the Netherlands, Alsace, and Switzerland). In contrast, the present-day Jewish community of South Africa is of the following makeup: most Jews trace their immediate ancestry to northern Lithuania; a smaller number to Latvia, Belarus, and the former Russian provinces of Lomza and Suvalki; and an even smaller number to other places. In Jewish geographical terms, we would say that most of contemporary South African Jewry is of Northeastern Ashkenazic descent (Northeastern Ashkenaz corresponds to present-day Lithuania, Latvia, Estonia, Belarus, and adjacent parts of Poland and Ukraine). Study of the kinds of Yiddish used in South Africa and of its vestiges in South African English and 
Afrikaans thus requires a knowledge of both Western Yiddish (for the earlier period) and Northeastern Yiddish.(for the later one). Indeed, all Yiddish-origin usages in Jewish South African English can be traced either to Western Yiddish or to Northeastern Yiddish, though sometimes it's hard to tell which of the two is relevant (and perhaps both are in certain instances). Jewish South African English vover 'six pence', for example, could just as easily be from Western as from Northeastern Yiddish. The third variety of Yiddish, Southern Yiddish, is the source of no usages and for good reason: relatively few speakers of Southern Yiddish have settled in South Africa.

Q. You're implying that vover was brought to South Africa. Could it not be a Jewish South African English coinage?

Possibly. The Yiddish names of the letters of the Hebrew alphabet have numerical values. Thus, alef is 'one', beys is 'two', giml is 'three' and so on down to the last letter of the alphabet (the eleventh letter stands for 'twenty'; the twelfth for 'thirty'; the twentieth letter 'two hundred'; etc. - it's more systematic than the Roman system because all of the Hebrew letters have numerical values and the values follow the alphabetical order of the letters). With the Yiddish names of the letters, you can form coin names by adding the suffix -er. Thus, beyser is the name of any coin worth two of something. And so on with heyer, vover, yuder, khof-heyer, and memer 'coin worth five, six, ten, twenty-five, forty....', respectively.

The model according to which the word was coined thus goes back to European Yiddish, but where and when vover was coined remain to be seen. If no other country where Yiddish-speakers have lived had minted a coin worth six of something, we would have to conclude that vover was minted (no pun intended!) in South Africa (by a speaker of Western or Northeastern Yiddish). However, Russia once minted a six-kopeck coin (called a zekser in Yiddish), Poland once minted a six-grosz coin (also called a zekser in Yiddish), Austria once minted a six-kreuzer coin (called a zekserl in Yiddish), and the United Kingdom once minted a half-shilling (six-pence) coin (whose Yiddish name or names I do not know). Any of those coins could easily have been called a vover. If so, the word was probably brought to South Africa rather than minted there. Thus, the pattern for the word is definitely pre-South-African and the word itself may be too (I have no evidence, however, that vover was ever used in Europe). Because the United States has never minted six-cent coins, the word has understandably been absent in (at least) post-independence American English (if such a coin was in circulation before the American Revolution, the few Ashkenazic Jews in the Thirteen Colonies could conceivably have used such a word). 


\section{Q. Jewish English, then, is not uniform the world over.}

Precisely. The differences are sometimes attributable to local general conditions (having nothing to do specifically with Jews), as in the case of vover: the existence of a six-pence coin in South Africa triggered use of the word vover (whether the word was coined in South Africa or brought from Europe being another matter), though it did not have to be used (Jews could have simply used whatever words non-Jews were using to designate the coin). Jewish American English, on the other hand, has no word meaning 'six-cent coin' because the United States has never minted a coin of that value.

Sometimes, however, local general conditions are irrelevant to spatial variation in Jewish English. That is, Jewish English has a certain dynamics of its own, independently of what local non-Jewish usage or conditions might be. Again, an example involving South Africa comes to mind. Certain varieties of Jewish English and Western Yiddish have a wish used before any fast. In the British Isles and South Africa, Jews wish one another Well over the fast! or Have an easy fast! (at least in the British Isles, the former is the older usage and the latter is the newer one). In Jamaica, Jews say Have a nice fast!. At least in Franconian Yiddish (but probably in many other varieties of Western Yiddish too), the wish is fast gut! 'fast well!' (Lowenstein 1975: 37). In Ashkenazic Berlin German, the wish is Gutes Fasten! (which is probably based on the Western Yiddish wish). In the United States, it seems that nothing is said, at least not today, (rather, here one asks solicitously AFTER a fast Did you have an easy fast?). The prejejunial wishes used by English-speaking Jews are not borrowed from non-Jewish English (for non-Jews have nothing comparable), but they could be non-literal translations of the Western Yiddish wish. The postjejunial question used in the United States is a translation of Eastern Yiddish d'host gehat a laykhtn tones? /ets hot gehat a laykhtn tones? /ir't gehat a laykhtn tones? We thus have several Jewish English usages in different parts of the world, all of them responding to a certain element of Jewish life, none of them being of non-Jewish English origin (except for the individual words making them up), at least one of them being a literal translation of an Eastern Yiddish usage, and the others probably being based on a Western Yiddish usage.

The specifically Jewish features of Jewish English therefore have a geography of their own, sometimes as a result of non-Jewish factors and sometimes as a result of Jewish factors. Yet one usually can't predict what the linguistic results of those Jewish and non-Jewish factors will be: Jews in South Africa did not have to use vover to designate a six-pence coin (but they did use it) nor do Jews anywhere have to have a special pre-fast wish (as they indeed do not have in the United States, whereas in the British Isles, South Africa, and Jamaica they do). Jewish English, like all other Jewish languages, thus results from what Max Weinreich called vertical (= Jewish) and horizontal (= non-Jewish) factors. The results of the interplay of those factors are to a large extent unpredictable. Jewish English is a subtle blend - those who think it's nothing more than 
"English with an admixture of Hebrew" (or Yiddish) are unacquainted with it, just as those who think it differs from non-Jewish English only in vocabulary overlook often subtle, often not so subtle Jewish specificities of pronunciation, morphology, semantics, syntax, style, and paralinguistics like gestures, facial expressions, and other body movements.

Study of Jewish South African English thus goes hand in hand with study of Jewish English elsewhere. Naturally, Jewish South African English and Jewish Afrikaans can't be investigated separately, just as South African English and Afrikaans in general must be taken together. To see even a small part of the picture you have to look at its entire sweep.

\section{Q. And the second part of your research on Jewish aspects of South African English and Afrikaans?}

The second part of my investigation of Jewish aspects of South African English and Afrikaans deals with how these two languages mirror the attitudes of nonJewish South Africans toward Jews. It is probably a universal of human history that outsiders (however they are defined) are regarded negatively. Probably all languages therefore have contemptuous words for such people (think, for example, of the derogatory words in South African English meaning 'Afrikaner').

I'm thus interested, for example, in how non-Jewish speakers of South African English and Afrikaans designate Jews and what other words and expressions they have which are of Jewish interest.

\section{Q. Even if words or expressions of Jewish interest are contemptuous?}

Yes. The linguist, as well as the lexicographer, is like a photographer who photographs people as they are, warts and all; like the botanist, who studies ugly as well as beautiful flowers; or like the zoologist, who studies clumsy as well as graceful animals. On the other hand, studying these usages dispassionately does not imply condoning them.

In trying to see how non-Jews in South Africa view Jews, we must also look at the situation elsewhere. Let's take as an example three entries from volume 5 of the Woordeboek van die Afrikaanse Taal:

[a] Jodebasaar 'woelige, deurmekaar plek waar baie geraas word' (as in "Dit gaan, lyk soos 'n Jodebasaar").

[b] Jodekerk 'gesê van 'n onordelike, rumoerige plek of byeenkoms, waar almal gelyk praat of deurmekaar skree' (as in 'Dit gaan soos [in], lyk soos, is 'n Jodekerk [hier]"). 
[c] Jodeskool 'verwarde gebabbel; die deurmekaar klink van stemme en geluide; lawaai' (as in "Die Jodeskool in die kinderkamer maak 'n mens dol") and 'wanordelike plek (kamer of huis) waar so 'n lawaai aangaan' (as in "Dis 'n regte Jodeskool daar").

Did Afrikaans-speakers themselves perceive Jews to be noisy and therefore innovate those usages? Or, rather, are they merely inherited from Dutch? Or are those usages borrowed from German? If the answer to the second or third question is yes, the Afrikaans usages are almost like dead metaphors, telling us little about how Afrikaans-speakers have perceived Jews. I say "little," because at least they show that Afrikaans-speakers haven't been loathe to using words which cast Jews in a bad light.

To examine these words in perspective, one must look at linguistic material from outside South Africa. Without going into the question in depth, I'll merely note that Bulgarian has evreiska xavra! 'what a noisy place!' (literally 'Jewish synagog!'). Turkish has çıfit çarsısı 'a noisy place' (literally 'sheeny market, sheeny bazaar', with a contemptuous word meaning 'Jew'). SerboCroatian ${ }^{1}$ has civutlija 'noisy game' (the word is derived from a contemptuous word meaning 'Jew'). Dutch has het lijkt wel een jodenkerk! 'what noise!' (literally 'it looks like a synagog!'). German has hier geht's zu wie in einer Judenschule! 'what a madhouse!' (literally 'this place is like a synagog!'). One of the meanings of Portuguese sinagoga (literally 'synagog') is 'noise, uproar, clamor; disorder, tumult'. Greek has an expression meaning 'disorderly place' which translates literally as 'Jewish synagog'. And it's been suggested that French brouhaha and English charivari go back to non-Jewish perceptions of Jewish prayer services as being particularly noisy (some take those suggestions to be proven, but to my mind the etymology of those two words needs more study).

More data from other languages could probably be cited, but the point is clear by now that in studying Afrikaans usages of Jewish interest, one must look at a range of languages - not only Dutch and South African English - in order to put matters into perspective. We see the value of that approach not only with respect to the Afrikaans expressions themselves but also with regard to the correct interpretation of jodeskool. If you consider the usages l've just mentioned; only Afrikaans jodeskool and German Judenschule seem to be different in that they appear to mean 'Jewish school' (cf. Afrikaans skool and German Schule 'school'), whereas the others refer to a synagog. Yet the original meaning of both jodeskool and Judenschule (or, in the case of the Afrikaans word, at least the original meaning of its Dutch etymon, jodenschool) was 'synagog' and not 'Jewish school', hence we have in these usages perfect semantic unity. To understand how jodeskool and Judenschule originally meant 'synagog', we have to look at Yiddish, where shul means both.'synagog' and 'school' (the pairing of those two meanings in the same word is found in several other Jewish languages as well; it came about as a result of the fact that Jewish schools were often housed in synagogs and because the synagog has always been what is 
called a bet-midrash, literally 'house of study', in Hebrew). Thus, if Yiddish shul has both meanings and if German Schule 'school' and Dutch school 'school' are cognate with Yiddish shul, the German and Dutch words, by analogy, can come to mean 'synagog' as well (= an instance of emulated polysemy). In the case of Dutch jodenschool, we may also suppose the semantic influence of German Judenschule (but only after the latter word came to mean 'synagog' too). Dutch jodenschool is the etymon of Afrikaans jodeskool, hence the assumption that the latter word once meant 'synagog'. Nowadays, however, in German, Dutch, and Afrikaans (but not in Yiddish and other Jewish languages), the meaning 'synagog' has been forgotten in these words and people interpret them to mean only 'Jewish school'.

In studying Jewish aspects of South African English and Afrikaans, one should observe more than just White English and White Afrikaans. For example, many English-speaking Cape Coloreds use Black Fast 'Day of Atonement (= the chief Jewish fast)'. This is a non-Jewish South African English coinage, no such word or analogous word being found in Jewish English, any other Jewish language, or any non-South-African variety of English that I know of. It appears that Black Fast was coined in Cape-Colored English and continues to be used only in this variety of English. Which brings me to another point.

Researchers are now paying more attention to spatial, ethnic, social, and chronological variation in South African English. Students of Afrikaans, I hope, are now paying more attention to ethnic and social variation (they have never neglected the diachrony of Afrikaans, for how the language emerged and developed has been a major topic on the agenda of Afrikaans research for many years; spatial variation in Afrikaans has also received attention).

Black Fast is an example of ethnic variation in non-Jewish South African English. Since, therefore, non-Jewish South African English and non-Jewish Afrikaans vary spatially, ethnically, socially, and chronologically, I wonder to what extent Jewish South African English and Jewish Afrikaans vary too (with respect to their specifically Jewish features). To take a hypothetical example, when six-pence coins were still used, might South African Jews in certain parts of the country have used vover whereas others did not? That question must be posed, not only because we know that non-Jewish South African English and Afrikaans vary (hence we must allow for the possibility of variation in Jewish varieties of these languages too), but also because we know from outside South Africa that Jewish English may vary spatially even within a single country. For example, in northern Eastern Ashkenazic British English ( = the English of Eastern Ashkenazim in Scotland and northern England) and in Ashkenazic Irish English, the word for 'skullcap' is traditionally yarmlke, whereas in southern Eastern Ashkenazic British English (= the English of Eastern Ashkenazim in southern England and in Wales), the word for 'skullcap' is traditionally kapl. That difference reflects a migration difference: many of the Eastern Ashkenazim in northern England, Scotland, and Ireland are of Northeastern Ashkenazic ancestry, whereas many of those in southern England and Wales are of 
Southern Ashkenazic ancestry. In Northeastern Yiddish (= the Yiddish of Northeastern Ashkenaz), the usual word for 'skullcap' is yarmlke and in Southem Yiddish (= the Yiddish of Southern Ashkenaz), a frequent word is kapl. Thus, spatial variation in Yiddish has been carried over into Eastern Ashkenazic British English.

Because Ashkenazim from many parts of Europe have settled in many parts of the British Isles, Ashkenazic British English is, expectedly, not uniform spatially. That is, because many varieties of Yiddish were brought to the British Isles and not all in the same measure everywhere, certain varieties of Ashkenazic British English have been more influenced by $x$ variety of Yiddish whereas other varieties of Ashkenazic British English have been more influenced by $y$ variety of Yiddish. And since non-Jewish British English varies from place to place, the non-Jewish features of Ashkenazic British English vary too. Thus, for instance, Ashkenazic Glasgow English is a function of non-Jewish Glasgow English and of whatever varieties of Yiddish happen to have influenced it (= horizontal and vertical factors, respectively).

In contrast to the situation in the British Isles, most Jews now living in South Africa trace their ancestry to a relatively small area: Lithuania and Latvia. The Yiddish of both of these countries is relatively uniform. The Ashkenazic community of contemporary South Africa is thus much more homogeneous linguistically and in other ways than that of the British Isles. It's therefore doubtful - but not impossible - that the specifically Jewish features of today's Jewish South African English or Jewish Afrikaans vary spatially. So far I haven't come across any spatial differences, but the matter needs to be investigated further.

\section{Q. We've spoken about South African English, Jewish South African En- glish, Jewish aspects of South African English, and Jewish aspects of non-Jewish Afrikaans, but not about Jewish Afrikaans.}

Perhaps intentionally so, for the study of Jewish Afrikaans has not yet begun. I remarked earlier that different groups of people use either different languages or different varieties of the same language. In the nineteenth and early twentieth centuries, many Jews coming to South Africa settled in Afrikaans-speaking areas, where they made their living usually as small shopkeepers or peddlers (Afrikaans smouse, English smouses). Afrikaans was thus either the first language which they acquired after coming to South Africa or, 'if they eventually learned English too, the stronger of the two languages. If they spoke Afrikaans to their children, these youngsters were native to the language. Solly Rechtman (to whom I owe all of this information on Afrikaans-speaking Jews) tells me that many such people, both foreign- and native-born, could be found earlier in this century, perhaps even into the 1920s. It stands to reason that at least in some respects the Afrikaans of these Jews has differed from that of non- 
Jews, though 1 have no examples at the moment. In the 1920s these Afrikaans. speaking Jewish communities began to disappear, as its members left for large cities, where they joined the local English-speaking Jewish communities. 1 suppose one can still find elderly Jews who speak Afrikaans natively or at least once spoke it better than English. They have to be interviewed as soon as possible.

\section{Q. You've also done work on family names and genealogy. Does it have a South African angle?}

Only a Jewish South African angle. What little has been written till now about Jewish family names in South Africa does not merit consideration. l've brought discipline into the field by treating these names scientifically. Nadine Gordimer, by the way, recently told me the origin of the name Gordimer and 1 hope to look into its history soon.

Some of my work in Jewish genealogy should be of interest especially to South African Jews - Northeastern Ashkenazim as most of them are. Because my father was a Northeastern Ashkenazi, my genealogical files are particularly rich for his area of Northeastem Ashkenaz, namely the towns of Anykšciai and Ukmergé, whose respective Yiddish names are aniksht and valkemir.

\section{Q. What may we expect from your pen in the future?}

I plan to continue reviewing monolingual and bilingual dictionaries published in South Africa, review work on family names in South Africa, and continue to study Jewish aspects of South African English and Afrikaans. The title of one of my planned articles will give you an idea of how wide the study of these two languages must often range: "From Egyptian mes/mesu 'child; son' - By Way of Hebrew, Yiddish, Dutch, Afrikaans, and British English - to South African English smous/smouse 'to peddle goods'." I also want to look into the English of Southern Rhodesia/Rhodesia/Zimbabwe. It has been said that at one time about half of the White population of Southern Rhodesia was Jewish (mostly Ashkenazic). Might such a large percentage of Jews not have left some linguistic traces of their presence?

I want to show the need for looking not only at form but also at meaning in Afrikaans etymology. For example, Afrikaans span 'team' is said to be from Dutch span 'team' and the etymology ends there. That's correct with respect to form, but when you look at meaning, something has to be added. The Dutch word refers to a team of animals and that was the original meaning (and still one of the meanings) of the Afrikaans word. However, when Afrikaans-speakers needed a word for 'team' in the sen'se of 'group of people constituting one side in a contest or competition' (a need which arose only in the nineteenth 
century), they took English as their model: if span = team in reference to a pair of animals, and if team also means 'group of people constituting one side in a contest or competition', then, by analogy, span came to be used in the latter sense as well. Call it literal translation, emulated polysemy, or whatever, Afrikaans is full of such items, few of which have been noted in the research literature. Another example is beperk in the names of companies and corporations, which translates English limited. And a third example may be borg in the sense of 'sponsor' (thus, the Nedbank is the "amptelike borg van die SuidAfrikaanse Olimpiese Span"/"the official sponsor of the South African Olympic Team"). As far as 1 can tell, neither Dutch beperkt nor borg are used in this way.

\section{Q. Can you summarize your work on South African English and Afrikaans?}

Speaking generally, I hope I've made two contributions: emphasizing the need to broaden perspectives and stressing the need to raise standards in etymology and in lexicography.

Till now, it seems that when students of South African English or of Afrikaans have considered languages outside southern Africa, they have looked chiefly at British English or European Dutch respectively. Occasionally they glance at Malay, Portuguese, German, languages of India, and perhaps French. All of that couldn't be more correct, but other languages shouldn't be neglected. American English is useful, as l've explained, in studying Afrikaans influence on South African English. Tristan da Cunha English shouldn't be overlooked either, for it and South African English share some features possibly absent in all other varieties of English. Without consideration of Western Yiddish and Northeastern Yiddish, one can't study Jewish South African English or Jewish Afrikaans properly. To investigate Jewish South African English, one must also look at Ashkenazic British English.

In general, I would like to show that Afrikaans can be better understood if it is compared with more languages than just European Dutch. For example, Gold 1990 shows that in children's counting-out rimes in languages ranging from American English across many languages of Europe to languages of Asia like Turkish, Armenian, Arabic and Marathi one can often discern a pattern in the first words of these rimes: the second word is an increment of a first one, that is, the second one consists of a preposed phoneme and the first word (thus, in American English, for example, eena meena), these two words usually being bisyllabic, in which case each of them is usually penultimately stressed; and the third word often, and the fourth word sometimes, have that same preposed phoneme as their first element (eena meena mina mo).

At least three Afrikaans children's counting-out rimes meet those requirements: ina dina daina das/skolle wina waina was/ink stink, die muskadel/ druif's gepluk - jy's uitgetel has three segments answering to the description 
I've just given (ina dina daina das... wina waina was... ink stink), as do Afrikaans rimes beginning ana drana... and olke bolke.... Which of the segments is of Dutch origin remains to be seen. So far, I've found olke bolke in a Dutch rime (olke bolke ribisolke/olke bolke knol), but not any of the other four. They might be of Dutch origin, but they could also be Afrikaans innovations. If they are innovations, we would conclude that Afrikaans-speaking children have inherited not only counting-out rimes from Dutch but also a pattern, which they have unconsciously used to create new rimes. The important point is thus that had we not looked at Afrikaans children's counting-out rimes in the broadest perspective possible the pattern in question might not have leaped to the eye so quickly and might not have been noticed at all.

Comparing the history of Afrikaans and of Yiddish helps to broaden one's perspective - or at least gives one the consolation of knowing that one's plight is not unique - because in looking at the two languages we see that their supporters have had to struggle to achieve an identity for them - and more or less in the same circumstances: Afrikaans has stood in the shadow of its "big brother," Dutch, and Yiddish has stood in the shadow of its "big brother," German. In both cases, linguistically naive detractors have used the same specious arguments against them ("Afrikaans is nothing more than corrupt Dutch" = "Yiddish is merely corrupted German") and the same pseudo-scientific, atomistic, reductionist tactic of trying to disprove the existence of these languages by pulling them apart, as if with tweezers, to show, supposedly, that this or that element "really isn't Afrikaans" or "really isn't Yiddish," but "actually" something else.

A case in point is ons in the sense of 'we'. A detractor of Afrikaans might argue along these lines: "since ons in the sense of 'we' is found in Dutch, it's not really Afrikaans." That approach, however, does not recognize the distinction which structural linguistics makes between etic and emic units or its requirement that linguistic systems be viewed as wholes. Of course ons 'we' in Afrikaans and ons 'we' in Zeeland Dutch are in an absolute (i.e., etic) sense identical, just as a yellow shirt in the United States, for example, and that same yellow shirt in Thailand are identical. Emically, however, Afrikaans ons and Dutch ons are not the same. In Afrikaans, ons 'we' is standard, universal, and competes with no variants: It is thus unmarked - the normal way of saying 'we'. In Dutch, on the other hand, this usage is limited (at least in recent years) to Zeeland (and even there it is not universal). In Dutch, it is regional and nonstandard, competing with standard and more widespread wij. Ons in the sense of 'we' is thus marked in Dutch. Similarly with yellow shirts. In the United States, yellow is just another color. In Thailand, however, yellow is a color reserved for the royal family. For someone not belonging to the royal family to wear yellow in Thailand would be a gross breach of etiquette. Therefore, a yellow shirt is a yellow shirt is a yellow shirt (etically identical the world over), but its emic status in Thailand is different from its emic status elsewhere. 
The detractors of Afrikaans and Yiddish thus look only at etic identities and not at emic differences. With a reductionist approach, you can deny the existence of practically anything (you and I don't exist - we're "merely" accumulations of atoms). If, however, we look at these two languages at close range, intimately, and not as the linguistically naive and uninformed armchair or cocktail-party pontificators do, we see that Afrikaans and Yiddish are in countless ways different from their supposed "big brothers."

As for the need to look at entire systems, when we look at Afrikaans or Yiddish in toto, it immediately becomes clear that neither of these two languages (or any variety of them) is identical with, respectively, Dutch or German (or any variety of them). Each is a unique finished product.

\section{Q. And with respect to raising standards?}

In recent years, the study of dictionaries has intensified in several countries. Lexicographical methods are being refined and today we require much greater rigor of people setting out to compile dictionaries than years ago. What Yakov Malkiel once said of etymology is no less true of lexicography and other branches of linguistics: "... a rehabilitation of etymology, through vigorous rejuvenation of its presuppositions and techniques, cannot be achieved by assiduous, painstaking accumulation of data alone. It requires the periodic cleansing and, if necessary, the bold replacement of antiquated tools, so as to enable etymologists to engage in a dialogue with other scholars on a high level of generality" (Malkiel 1976: vii).

\section{Note}

1 D.L.G. comments: "The usual spelling in English is Serbo-Croatian, but Morton Benson and other students of the language use SerboCroatian in order to emphasize that this is a single language, with two major varieties, the eastern one being the standard in Serbia and the western one the standard in Croatia (see Benson's SerboCroatian-English Dictionary, third edition, Belgrade, Prosveta, 1988). The solid spelling stresses the unity of the language and the internal capital letter stresses the fact that both varieties are equally acceptable (hence CroatoSerbian is also used). Although an internal capital is not frequent in English, it is not absent: we find it in Irish and Scottish family names (those with the prefix $M c$ are regularly written solid and with an internal capital, like McGrath, and those with Mac may be written solid, in which case an internal capital is used, as in MacGorman), in the names of some products (like WordPerfect), and in certain prefixed African-origin English words (like amaBunu, eBhayi, eGoli, eRawutini, eThekwini, iJuba, iJuvi, isiBhulu, isiNiu; isiZulu, kwaZulu, and Mayibuye iAfrika, all of which are in Branford 1991). It may also be noted that in 1959 the Royal Spanish Academy decided that certain compounds should be spelled solid unless they expressed a contrast or opposition, in which case they were to be hyphenated. For example, la guerra anglo-boer 'the Anglo-Boer War' vs. una persona de ascendencia angloboer 'a person of Anglo-Boer descent: 
Precedents can thus be found for the spelling SerboCroatian, which is a linguist's minuscule yet important protest at the madness now prevalent in the Balkans, where speakers of SerboCroatian, who once constituted a single people, have been riven into three by religious differences.

Afrikaans has a distinct advantage over English in that it has an excellent spelling system, in which the fit between phoneme and grapheme could probably not be better. The chaos of English spelling and the orderliness of Afrikaans spelling could thus not be in starker contrast. Afrikaans has that good fortune thanks to its having a commission which sets the official spelling for everyone writing the language. Since in a well-ordered society a certain degree of discipline is expected of all its members, I accept the spelling rules of the Afrikaans Language Commission of the South African Academy of Arts and Sciences, which allow only for Serwo-Kroaties (cf. the Afrikaans keywords of this interview), even though that spelling is not consistent with Serbocroatian. On the other hand, innovations which enhance understanding only enhance the very goal of language itself. Perhaps, then, the language commission will consider accepting SerwoKroaties (at least as an alternate spelling) and thus, like Engish-writing linguists who prefer Serbocraatian, make its tiny but important contribution to peace."

\section{References}

Branford, Jean with William-Branford. 1991. A Dictionary of South African English. 1991. Cape Town: Oxford University Press [rev. Gold 1992].

Carpenter, William H. 1908. "Dutch Contributions to the Vocabulary of English in America: Dutch Remainders in New York State." Modern Philology Vl: 53-68.

Gold, David L. 1981. "Three New-York-Cityisms: sliding pond, potsy, and akey." American Speech 56: 17-32.

Gold, David L. 1984. "More on a Dutch-Origin Word in New York City English: sliding pon(d)." Leuvense Bijdragen 73: 171-175.

Gold, David L. 1986. "Still More on the Origin of New York City English sliding pon(d)." Leuvense Bijdragen 75: 335-357.

Gold, David L. 1990. "Some Yiddish, Judezmo, and Hebrew Children's Counting-Out Rimes in Their European Context and Evidence Against the Suggestion That the First Line of the English Children's Counting-Out Rime eena meena mina mo May Be of São Tomense Origin." Jewish Linguistic Studies 2: 84-104.

Gold, David L. 1992. "On the Fourth Edition of A Dictionary of South African English." Lexikos 2: 85-136.

Gold, David L. In prep. "From Egyptian mes/mesu 'child; son' - By Way of Hebrew, Yiddish, Dutch, Afrikaans, and British English - to South African English smous/smouse to peddle goods'."

Lowenstein, Steven. 1975. "Remnants of Franconian Yiddish (Part 3)." Yidishe Shprakh XXXIV: 37. 43.

Malkiel, Yakov. 1976. Etymological Dictionaries: A Tentative Typology. Chicago and London: The University of Chicago Press.

Shetter, William Z. 1958. "A Final Word on Jersey Dutch." American Speech 33: 243-251. 